\title{
COVID-19 preventive behaviors and influencing factors in the Iranian population; a web-based survey
}

\author{
Mojgan Firouzbakht ${ }^{1}$, Shabnam Omidvar ${ }^{2 *}$, Saeedeh Firouzbakht ${ }^{3}$ and Arman Asadi-Amoli $^{4}$
}

\begin{abstract}
Background: COVID19 is a respiratory disease caused by a novel coronavirus. As there has been no definitive treatment for the disease so far, the only way to control the spread is to break the chain of infection. Our study aimed to analyze the preventive behaviors and influencing factors in the Iranian population.

Methods: This cross-sectional study was a web-based survey in the Iranian population. We performed the study during the first peak of COVID-19 outbreak (from March 25th, 2020 to April 5th). We used demographic and Preventive behaviors questionnaires to collect the data. This web-based survey was publicized on the internet through the common platforms used by the Iranian population. This survey was released on the website "Porsline. com". A total of 2097 acceptable questionnaires were filled. All data were analyzed, using Statistical Package for Social Sciences (SPSS) version 19.

Results: $61.9 \%$ of the participants checked the hand-washing question as "Always". 55.7 and $58.2 \%$ checked the wearing masks and gloves as "Always", respectively. We found a significant relationship between gender and hand washing behavior $(P=0.006)$ and the use of masks and gloves $(P<0.001)$. Results showed that wearing gloves had a significant relation with the education status $(P=0.029)$ and economic status $(P=0.011)$. Wearing masks had a significant relation with economic status $(P=0.032)$. Overall women had better preventive behaviors.
\end{abstract}

Conclusions: Preventive behaviors have a significant relation with some socio-demographic characteristics. According to the 3 main preventive behaviors of hand-washing, wearing masks and gloves $50 \%$ of the population has not taken these behaviors seriously.

Keywords: Preventive behaviors, Online survey, COVID-19, Web-based

\section{Background}

COVID19 is a respiratory disease caused by a new coronavirus, first found in December 2019 in Wuhan, China. The disease is highly contagious, and its symptoms include fever, fatigue, dry cough, muscular pain, and dyspnea. It has been reported that $18.5 \%$ of the Chinese patients, developed to the severe stage, which

\footnotetext{
* Correspondence: shomidvar@yahoo.com

${ }^{2}$ Social Determinants of Health Research Center, Health Research Institute, Babol University of Medical Sciences, Babol, Iran

Full list of author information is available at the end of the article
}

leads to Acute Respiratory Distress Syndrome (ARDS), Acidosis, Septic Shock, Bleeding, and Disseminated Intravascular Coagulation (DIC) $[1,2]$.

Different medications were used in various treatment protocols to experiment with lethality control of the disease in clinical trials. Some of these medications proved to reduce lethal complications $[3,4]$.

The epidemic outbreak of COVID19 was so fast that it had spread to 26 different countries by February 15, 2020 [5] and by the end of the same month, 85,681 cases and 2933 deaths were reported; most of which were

C C The Author(s). 2021 Open Access This article is licensed under a Creative Commons Attribution 4.0 International License, which permits use, sharing, adaptation, distribution and reproduction in any medium or format, as long as you give appropriate credit to the original author(s) and the source, provide a link to the Creative Commons licence, and indicate if changes were made. The images or other third party material in this article are included in the article's Creative Commons licence, unless indicated otherwise in a credit line to the material. If material is not included in the article's Creative Commons licence and your intended use is not permitted by statutory regulation or exceeds the permitted use, you will need to obtain permission directly from the copyright holder. To view a copy of this licence, visit http://creativecommons.org/licenses/by/4.0/ The Creative Commons Public Domain Dedication waiver (http://creativecommons.org/publicdomain/zero/1.0/) applies to the data made available in this article, unless otherwise stated in a credit line to the data. 
reported by China [6]. On January 30, 2020, the World Health Organization (WHO), declared this epidemic outbreak as a Global Health Emergency [7]. On 8th of April 1,282,931 confirmed cases, 72,616 confirmed deaths were reported by WHO [8]. The first diagnosed cases in Iran were confirmed on February 19, 2020 in Qom, and the rapid spread of the disease caused the contagion of more states. The states of Golestan, Mazandaran, Tehran, and Isfahan were reported as red regions [9].

COVID-19 is transmitted from person to person through direct contact, infected surfaces, droplets, and fecal-oral contact, and the incubation period ranges from 2 to 14 days. According to a report by WHO, by April 14,2020 , over 1 million cases and 50,000 deaths had occurred, since the outbreak of this disease; which is fearsome statistics.

Health is one of the basic rights of human beings and is generally considered a personal duty. The Self-care ability of each person is highly affected by factors, such as age, lifestyle, health status, emotional status, and knowledge. Self-care is defined as activities and precautions which a person takes, to prevent or control infections; in other words, precautions that are taken without professional help $[10,11]$. In most the infectious disease, self-hygiene is the cheapest and easiest way to prevent infections.

By the end of January 2020, WHO and the Centers for Disease Control and Prevention (CDC), published a series of recommendations to prevent the spread of COVID19 [12, 13].

As there has been no definitive treatment, reported for this disease, the only way to control the spread is to break the chain of infection. Everyone has to stay home and follow the self-care guidelines that were recommended by the WHO; however, there is no data relating the preventive behaviors of the Iranian population, Hence, this study aimed to analyze the preventive behaviors of the Iranian population.

\section{Methods}

Study design

This cross-sectional study was conducted among the Iranian population. To prevent the spread of COVID-19 through contact, the data we collected through a webbased survey. This web-based survey was broadcasted on the internet through the common platforms used by the Iranian population. This survey was released on the website "Porsline.com"https://survey.porsline.ir/\#/survey/56 871/build. Inclusion Criteria included self-reported Iranian nationality and age 16 years and above.

\section{Data collection}

The participant answered the questions anonymously, from March 25th, 2020 to April 5th. All study participants answered the socio-demographics and preventive behavior questions. This web-based questionnaire was filled, completely voluntarily. To ensure the quality of the survey, we set the 5-point-Likert (Always, most of the time, sometimes, rarely, never). The questionnaire that was filled in less than $1 \mathrm{~min}$ or more than $15 \mathrm{~min}$, were excluded. The questionnaire was observed by 3500 and a total of 2097 questionnaires were filled.

\section{Measures}

\section{Demographic information}

Demographic variables including the name of the state, gender (male, female), age (years), marital status (single, married, widowed, divorced), education (High school, Graduate, Postgraduate.), occupation (Unemployed, worker/farmer, Government employee, Self-employed, student), economic status (Good, Average, Bad) were asked in this section.

\section{Preventive behaviors}

The questionnaire was designed by the authors, with attention to preventive guidelines, presented by the Iranian ministry of health and treatment and WHO [12]. The questionnaire had 33 questions in four domains. Individual behavior (13 questions), guidelines for entering and leaving the home ( 8 and 8 questions, respectively), preventive guidelines for using personal belongings (4 questions). As COVID19 is a rapidly spreading and highly contagious disease, the participants that answered "always" are given " 1 ", and the other choices are scored as " 0 "; hence, the scores range from 0 to 33; where higher score indicated better preventive behavior. We determined the validity and reliability of the questionnaire. Eleven experts rated the items, and the content validity indices (CVI) of the questionnaire were calculated to be 0.81 . The Cronbach's alpha of the questionnaire was 0.82 , indicating internal consistency.

\section{Statistical analysis}

To identify factors influencing COVID-19 preventive behavior, multiple linear regression analysis was performed, and to determine the odds of preventive behavior, Logistic regression analysis was performed. All data were analyzed, using Statistical Package for Social Sciences (SPSS) version 19. P-values of less than 0.05 were considered statistically significant (2-sided tests).

\section{Results}

This cross-sectional study was conducted in a way that 31 states contributed to the data for the study. The states of Tehran (24.9\%) and Mazandaran (22\%) had the highest contribution to the data pool; contrary to the state of Ilam $(0.1 \%)$ with the lowest contribution. According to Porsline online survey system, the responding rate was $78 \%$ and the average duration of filling the 
Table 1 Comparison of demographic characteristics by preventive behavior domains

\begin{tabular}{|c|c|c|c|c|c|c|c|c|c|c|c|c|c|c|}
\hline & & \multirow[b]{3}{*}{$\mathrm{N}(\%)$} & \multicolumn{12}{|c|}{ Preventive behavior } \\
\hline & & & \multicolumn{3}{|c|}{ Individual behavior } & \multicolumn{3}{|c|}{ Entering guidelines } & \multicolumn{3}{|c|}{ Leaving guidelines } & \multicolumn{3}{|c|}{$\begin{array}{l}\text { Personal } \\
\text { belongings' } \\
\text { guidelines }\end{array}$} \\
\hline & & & $\begin{array}{l}\text { Mean } \\
\text { (SD) }\end{array}$ & ${ }^{*} \mathrm{~T} / \mathrm{F}$ & $P$ & $\begin{array}{l}\text { Mean } \\
\text { (SD) }\end{array}$ & $\begin{array}{l}{ }^{*} \mathrm{~T} / \\
\mathrm{F}\end{array}$ & $\mathbf{P}$ & $\begin{array}{l}\text { Mean } \\
\text { (SD) }\end{array}$ & ${ }^{*} \mathrm{~T} / \mathrm{F}$ & $\mathbf{P}$ & $\begin{array}{l}\text { Mean } \\
\text { (SD) }\end{array}$ & $\begin{array}{l}{ }^{*} \mathrm{~T} / \\
\mathrm{F}\end{array}$ & $\mathbf{P}$ \\
\hline \multirow[t]{2}{*}{ Gender } & Female & $\begin{array}{l}1503 \\
(71.7)\end{array}$ & $\begin{array}{l}8.12 \\
(2.40)\end{array}$ & 9.84 & $<.001$ & $\begin{array}{l}6.038 \\
(5.205)\end{array}$ & 9.16 & $<.001$ & $\begin{array}{l}5.423 \\
(1.891)\end{array}$ & 13.06 & $<.001$ & $\begin{array}{l}3.859 \\
(1.41)\end{array}$ & 8.65 & $<.001$ \\
\hline & Male & $\begin{array}{l}594 \\
(28.3)\end{array}$ & $\begin{array}{l}6.93 \\
(2.70)\end{array}$ & & & $\begin{array}{l}5.205 \\
(2.107)\end{array}$ & & & $\begin{array}{l}4.161 \\
(2.133)\end{array}$ & & & $\begin{array}{l}3.237 \\
(1.65)\end{array}$ & & \\
\hline \multirow[t]{6}{*}{ Age } & $<20$ & $83(4)$ & $\begin{array}{l}7.59 \\
(2.55)\end{array}$ & 1.56 & .166 & $\begin{array}{l}5.54 \\
(1.93)\end{array}$ & 4.72 & $<.001$ & $5.03(2.18)$ & 3.46 & .004 & $\begin{array}{l}3.61 \\
(1.56)\end{array}$ & 1.68 & .135 \\
\hline & $20-30$ & $\begin{array}{l}698 \\
(33.8)\end{array}$ & $\begin{array}{l}7.64 \\
(2.61)\end{array}$ & & & $\begin{array}{l}5.59 \\
(1.98)\end{array}$ & & & $\begin{array}{l}4.81 \\
(2.08)\end{array}$ & & & $\begin{array}{l}3.66 \\
(1.46)\end{array}$ & & \\
\hline & $31-40$ & $\begin{array}{l}775 \\
(37.5)\end{array}$ & $\begin{array}{l}7.95 \\
(2.44)\end{array}$ & & & $\begin{array}{l}5.85 \\
(1.88)\end{array}$ & & & $\begin{array}{l}5.15 \\
(2.02)\end{array}$ & & & $\begin{array}{l}3.76 \\
(1.49)\end{array}$ & & \\
\hline & $41-50$ & $330(16)$ & $\begin{array}{l}7.81 \\
(2.56)\end{array}$ & & & $\begin{array}{l}6.17 \\
(1.72)\end{array}$ & & & $\begin{array}{l}5.31 \\
(1.97)\end{array}$ & & & $\begin{array}{l}3.65 \\
(1.55)\end{array}$ & & \\
\hline & $51-60$ & $\begin{array}{l}152 \\
(7.4)\end{array}$ & $\begin{array}{l}7.72 \\
(2.65)\end{array}$ & & & $\begin{array}{l}5.75 \\
(1.98)\end{array}$ & & & $\begin{array}{l}5.14 \\
(1.94)\end{array}$ & & & $\begin{array}{l}3.55 \\
(1.58)\end{array}$ & & \\
\hline & $>60$ & $30(1.5)$ & $\begin{array}{l}7.23 \\
(2.67)\end{array}$ & & & $5.6(2.11)$ & & & $5.33(2)$ & & & $\begin{array}{l}3.06 \\
(1.68)\end{array}$ & & \\
\hline \multirow[t]{4}{*}{ Marital status } & Single & $775(37)$ & $\begin{array}{l}7.72 \\
(2.57)\end{array}$ & .70 & .54 & $\begin{array}{l}5.57 \\
(1.98)\end{array}$ & 5.91 & .001 & $\begin{array}{l}4.83 \\
(2.08)\end{array}$ & 5.51 & .001 & $\begin{array}{l}3.60 \\
(1.49)\end{array}$ & 1.91 & .12 \\
\hline & Married & $\begin{array}{l}1242 \\
(59.2)\end{array}$ & $\begin{array}{l}7.81 \\
(2.55)\end{array}$ & & & $\begin{array}{l}5.92 \\
(1.87)\end{array}$ & & & $\begin{array}{l}5.19 \\
(2.01)\end{array}$ & & & $\begin{array}{l}3.72 \\
(1.52)\end{array}$ & & \\
\hline & Divorce & $64(3.1)$ & $\begin{array}{l}8.5 \\
(1.89)\end{array}$ & & & $\begin{array}{l}6.31 \\
(1.53)\end{array}$ & & & $\begin{array}{l}5.43 \\
(1.75)\end{array}$ & & & $\begin{array}{l}3.31 \\
(1.49)\end{array}$ & & \\
\hline & Widowed & $16(.8)$ & $\begin{array}{l}7.93 \\
(2.42)\end{array}$ & & & $\begin{array}{l}5.96 \\
(1.60)\end{array}$ & & & $\begin{array}{l}5.32 \\
(1.79)\end{array}$ & & & $\begin{array}{l}3.93 \\
(1.40)\end{array}$ & & \\
\hline \multirow[t]{3}{*}{ Education } & High school & $\begin{array}{l}449 \\
(21.3)\end{array}$ & $\begin{array}{l}7.47 \\
(2.65)\end{array}$ & 4.43 & .012 & $\begin{array}{l}5.71 \\
(1.97)\end{array}$ & .814 & .443 & $\begin{array}{l}5.10 \\
(2.03)\end{array}$ & 2.18 & .113 & $\begin{array}{l}3.52 \\
(1.59)\end{array}$ & 5.52 & .004 \\
\hline & Graduate & $\begin{array}{l}1036 \\
(49.4)\end{array}$ & $\begin{array}{l}7.88 \\
(2.58)\end{array}$ & & & $\begin{array}{l}5.85 \\
(1.89)\end{array}$ & & & $\begin{array}{l}5.13 \\
(2.03)\end{array}$ & & & $\begin{array}{l}3.78 \\
(1.47)\end{array}$ & & \\
\hline & Postgraduate & $\begin{array}{l}615 \\
(29.3)\end{array}$ & $\begin{array}{l}7.85 \\
(2.39)\end{array}$ & & & $\begin{array}{l}5.78 \\
(1.89)\end{array}$ & & & $\begin{array}{l}4.92 \\
(2.05)\end{array}$ & & & $\begin{array}{l}3.62 \\
(1.49)\end{array}$ & & \\
\hline \multirow[t]{5}{*}{ Occupation } & Unemployed & $\begin{array}{l}613 \\
(29.2)\end{array}$ & $\begin{array}{l}7.89 \\
(2.52)\end{array}$ & 3.30 & .010 & $\begin{array}{l}5.94 \\
(1.78)\end{array}$ & 2.33 & .054 & $\begin{array}{l}5.35 \\
(1.89)\end{array}$ & 5.18 & $<.001$ & $\begin{array}{l}3.85 \\
(1.49)\end{array}$ & 4.32 & .002 \\
\hline & Farmer/worker & $37(1.8)$ & $\begin{array}{l}6.78 \\
(2.46)\end{array}$ & & & $\begin{array}{l}5.21 \\
(1.88)\end{array}$ & & & $\begin{array}{l}4.41 \\
(2.14)\end{array}$ & & & $\begin{array}{l}3.29 \\
(1.57)\end{array}$ & & \\
\hline & $\begin{array}{l}\text { Government } \\
\text { Employee }\end{array}$ & $\begin{array}{l}669 \\
(31.9)\end{array}$ & $\begin{array}{l}7.87 \\
(2.58)\end{array}$ & & & $\begin{array}{l}5.81 \\
(1.95)\end{array}$ & & & $\begin{array}{l}5.00 \\
(2.11)\end{array}$ & & & $\begin{array}{l}3.59 \\
(1.530\end{array}$ & & \\
\hline & Self employed & $\begin{array}{l}451 \\
(21.5)\end{array}$ & $\begin{array}{l}7.52 \\
(2.62)\end{array}$ & & & $\begin{array}{l}5.72 \\
(1.97)\end{array}$ & & & $\begin{array}{l}4.87 \\
(2.07)\end{array}$ & & & $\begin{array}{l}3.54 \\
(1.54)\end{array}$ & & \\
\hline & student & $\begin{array}{l}327 \\
(15.6)\end{array}$ & $\begin{array}{l}7.91 \\
(2.40)\end{array}$ & & & $\begin{array}{l}5.67 \\
(1.94)\end{array}$ & & & $\begin{array}{l}4.99 \\
(2.04)\end{array}$ & & & $\begin{array}{l}3.75 \\
(1.38)\end{array}$ & & \\
\hline \multirow[t]{3}{*}{ Economic Status } & Good & $\begin{array}{l}400 \\
(19.1)\end{array}$ & $\begin{array}{l}8.17 \\
(2.41)\end{array}$ & 10.14 & $<.001$ & $\begin{array}{l}6.07 \\
(1.75)\end{array}$ & 9.9 & $<.001$ & $\begin{array}{l}5.38 \\
(1.90)\end{array}$ & 5.79 & .003 & $\begin{array}{l}3.77 \\
(1.48)\end{array}$ & .835 & .434 \\
\hline & Average & $\begin{array}{l}1431 \\
(68.2)\end{array}$ & $\begin{array}{l}7.77 \\
(2.52)\end{array}$ & & & $\begin{array}{l}5.80 \\
(1.90)\end{array}$ & & & $\begin{array}{l}4.99 \\
(2.04)\end{array}$ & & & $\begin{array}{l}3.65 \\
(1.51)\end{array}$ & & \\
\hline & Bad & $\begin{array}{l}266 \\
(12.7)\end{array}$ & $\begin{array}{l}7.27 \\
(2.78)\end{array}$ & & & $\begin{array}{l}5.40 \\
(2.08)\end{array}$ & & & $\begin{array}{l}4.97 \\
(2.16)\end{array}$ & & & $\begin{array}{l}3.68 \\
(1.53)\end{array}$ & & \\
\hline \multirow[t]{2}{*}{$\begin{array}{l}\text { Chronic health } \\
\text { condition }\end{array}$} & Yes & $\begin{array}{l}175 \\
(8.3)\end{array}$ & $\begin{array}{l}7.78 \\
(2.62)\end{array}$ & -.19 & .84 & $\begin{array}{l}5.81 \\
(2.06)\end{array}$ & .18 & .85 & $\begin{array}{l}5.04 \\
(2.02)\end{array}$ & -.29 & .76 & $\begin{array}{l}3.71 \\
(1.51)\end{array}$ & -.16 & .87 \\
\hline & No & 1504 & 7.82 & & & 5.78 & & & 5.09 & & & 3.73 & & \\
\hline
\end{tabular}


Table 1 Comparison of demographic characteristics by preventive behavior domains (Continued)

\begin{tabular}{|c|c|c|c|c|c|c|c|c|c|c|c|c|}
\hline & \multicolumn{12}{|c|}{ Preventive behavior } \\
\hline & \multicolumn{3}{|c|}{ Individual behavior } & \multicolumn{3}{|c|}{ Entering guidelines } & \multicolumn{3}{|c|}{ Leaving guidelines } & \multicolumn{3}{|c|}{$\begin{array}{l}\text { Personal } \\
\text { belongings' } \\
\text { guidelines }\end{array}$} \\
\hline $\mathrm{N}(\%)$ & $\begin{array}{l}\text { Mean } \\
\text { (SD) }\end{array}$ & ${ }^{*} \mathrm{~T} / \mathrm{F}$ & $\mathbf{P}$ & $\begin{array}{l}\text { Mean } \\
\text { (SD) }\end{array}$ & $\begin{array}{l}{ }^{*} \mathrm{~T} / \\
\mathrm{F}\end{array}$ & $\mathbf{P}$ & $\begin{array}{l}\text { Mean } \\
\text { (SD) }\end{array}$ & ${ }^{*} \mathrm{~T} / \mathrm{F}$ & $\mathbf{P}$ & $\begin{array}{l}\text { Mean } \\
\text { (SD) }\end{array}$ & $\begin{array}{l}{ }^{*} \mathrm{~T} / \\
\mathrm{F}\end{array}$ & $P$ \\
\hline$(71.7)$ & $(2.50)$ & & & $(1.87)$ & & & (2.01) & & & $(1.47)$ & & \\
\hline
\end{tabular}

*Independent t-test/ANOVA

survey was $5 \mathrm{~min}$ and $13 \mathrm{~s}$. The questionnaire was filled by 2097 people, where $73 \%$ of them were directed to the survey through the online messaging app (98\% of the surveys were filled by mobile phones). The participants' general characteristics and COVID- 19 related preventive behavior were analyzed using frequencies, percentages, mean, and standard deviations. Differences in preventive behavior were analyzed according to general characteristics, utilizing independent t-test, ANOVA, and post-hoc Scheffe test.

The mean age of the participants was $34.85 \pm 10.26$ years, and $71.6 \%$ of them were women. Preventive behaviors were studied in an overall analysis, as well as in 4 separate domains. The mean overall score was $22.46 \pm$ 6.38 out of 33 . The relation between the preventive behavior domains and socio-demographic characteristics is presented in Table 1.

Among the individual preventive behaviors, the most emphasized ones (Washing the hands for at least $20 \mathrm{~s}$, wearing a mask, and wearing gloves) were studied separately. $61.9 \%$ of the participants checked the handwashing question as "Always", however, 51.7 and 41.8\% of them, did not check wearing gloves and masks as "Always", respectively (Table 2). We found a significant relationship between gender and hand washing behavior $(P=0.006)$ and the use of masks and gloves $(P<0.001)$. Women had better preventive behavior in all domains. We also found that wearing gloves had a significant relation with the education status $(P=0.029)$ and economic status $(P=0.011)$. Wearing masks had a significant relation with economic status $(P=0.032)$.

Linear regression analysis was used to study the predictive behaviors. In linear univariate regression analysis, age $(P=0.016)$, Gender $(P \leq 0.001)$, economic status $(P=$ $0.001)$ were the predictive variables, and in multivariate linear regression analysis, gender, economical status $(\mathrm{P} \leq$ $0.001)$ and age $(P=0.001)$ were the predictive variables. Table 3 shows that the adjusted linear regression variables, predict the domains.

Logistic regression analysis was performed to assess odds ratio of preventive behaviors according to sociodemographic in Table 4. We found that the chance of appropriate preventive behaviors in all the domains was two times better in women than men. Other variables are presented in the table.

\section{Discussion}

The present study is the first to investigate preventive behaviors throughout Iran. It was conducted when there were more than 27,000 patients and 2000 mortality cases due to COVID-19 according to the official statistics, given by the authorities. All Schools, Universities, and public places were closed for a month, before this study, and quarantine was imposed on all. We studied preventive behaviors and the personal and social factors affecting the target behaviors in a sample of candidates of over 15 years of age.

COVID-19 can spread from person to person. Many of the carriers of the virus show absolutely no symptoms and they are the main reason behind the spread of the virus. The virus can spread through droplets as well as direct contact with infected persons. Therefore, Personal Preventive Equipment (PPE), can contribute to controlling the spread $[14,15]$.

A study on the MERS Coronavirus proved that the people who are more prone to the infection showed better preventive behaviors. The results complied the theory that suggests the risk perception of infectious diseases promotes proper preventive behaviors. This suggests that risk perception can contribute to controlling the spread [16]. Socio-demographic status plays an important role in risk perception $[17,18]$.

Among the individual preventive behaviors, the most emphasized ones (Washing the hands for at least $20 \mathrm{~s}$, wearing a mask, and wearing gloves) were studied separately. As it has been mentioned in the results, only $61.9 \%$ of the participants declared that they always wash their hands for at least $20 \mathrm{~s}$. As hand-washing has always been important behavior related to personal health, there have been many studies in this field. Borchgrevink et al. conducted a study on 3749 individuals and concluded that only $5 \%$ of the people wash their hands properly and for more than $15 \mathrm{~s}$ [19]. These studies showed that insufficient attention is being paid to this preventive behavior. 
Table 2 Percentage of positive response to preventive behavior

\begin{tabular}{|c|c|}
\hline Items & $\begin{array}{l}\text { Positive response } \\
N(\%)\end{array}$ \\
\hline \multicolumn{2}{|l|}{ Individual behaviors } \\
\hline I do NOT leave home, unless it is necessary & $935(44.6)$ \\
\hline I avoid handshakes and hugging others & $1845(88)$ \\
\hline I keep a minimum distance of $1.5 \mathrm{~m}$ from others & $980(46.5)$ \\
\hline I avoid touching my face (eyes, nose and mouth) & $345(31.2)$ \\
\hline I regularly wash my hands for AT LEAST $20 \mathrm{~s}$ & $1298(61.9)$ \\
\hline I wear disposable gloves when I leave the house & $1013(48.3)$ \\
\hline I cover my mouth and nose while sneezing or coughing & $1572(75.2)$ \\
\hline I dispose of tissue papers in a lidded trash can & $1461(69.7)$ \\
\hline I DO NOT visit friends and relatives & $1268(60.5)$ \\
\hline I DO NOT attend birthday parties, wedding parties, or any other parties & $1657(79)$ \\
\hline I DO NOT eat out & $1764(84.1)$ \\
\hline I DO NOT use public transportation & $1885(89.9)$ \\
\hline I disinfect my work space surfaces before anything else & $1546(73.7)$ \\
\hline \multicolumn{2}{|l|}{ Practices when entering the house } \\
\hline I wash my hands before taking off my clothes or do any other task & $1571(74.9)$ \\
\hline I dry my hands using tissue papers & $1967(93.8)$ \\
\hline I dispose of the tissue paper in a lidded trash can & $1112(53)$ \\
\hline I disinfect my belongings such as cellphone, keys, wallet, etc. using alcohol disinfectant (70\% alcohol) & $1461(69.7)$ \\
\hline I hang my clothes separately from other clothes when I enter the house & $1513(72.2)$ \\
\hline I wash my hands again, after removing my clothes & $1281(61.1)$ \\
\hline I wash my hands after using the WC and before eating & $1380(65.8)$ \\
\hline I disinfect all surfaces, everyday & $1883(89.8)$ \\
\hline \multicolumn{2}{|l|}{ Practices when leaving the house } \\
\hline I ask myself about the necessity, when I am leaving the house & $926(44.2)$ \\
\hline I take alcohol disinfectant with me & $1298(61.9)$ \\
\hline I wear disposable masks & $1169(55.7)$ \\
\hline I wear disposable gloves & $1221(58.2)$ \\
\hline I do not leave the house in case I have symptoms of fever and cough & 1249 (59.6) \\
\hline I leave the house wearing a mask, in case I have symptoms of fever and cough & $1695(80.8)$ \\
\hline I always carry clean tissue papers & $1501(71.6)$ \\
\hline I do not touch elevator buttons with bare hands & $1414(67.4)$ \\
\hline \multicolumn{2}{|l|}{ Practices while using personal belongings } \\
\hline I do not take my cell phone out of my pocket when outside, unless there is an emergency & $1243(59.3)$ \\
\hline I do not remove my glasses or wrist-watch when outside & $1464(69.8)$ \\
\hline I do not place my belongings on surfaces I am not certain of their hygiene & $1615(77)$ \\
\hline I take food (Meat, chicken, eggs, etc.) only in a well done doneness & $1856(88.5)$ \\
\hline
\end{tabular}

A significant relation was realized to exist between the demographic status of gender, education and economic status, and the preventive behaviors of hand-washing, wearing masks, and protective gloves. This study showed that women have better preventive behavior comparison to men. Many studies conclude women are more cautious and preventive about infectious diseases. Moreover, housewives tend to have better preventive behavior [20-22]. Our results comply with a study by Wolf et al. which suggests that women have taken the new Corona Virus, more seriously, and people with lower economic status have not taken the disease seriously [23]. 
Table 3 Adjusted model linear regression predictive prevention behavior against covid-19 in four domains. $(n=2097)$

\begin{tabular}{|c|c|c|c|c|c|c|c|c|c|c|c|c|}
\hline \multirow[t]{2}{*}{ variables } & \multicolumn{3}{|c|}{ Individual behavior } & \multicolumn{3}{|c|}{ Entrance behavior } & \multicolumn{3}{|c|}{ Leaving protocols } & \multicolumn{3}{|c|}{ Personal belongings } \\
\hline & $\bar{\beta}$ & $\mathrm{t}$ & $p$ & $\beta$ & $t$ & $p$ & $\beta$ & $\mathrm{t}$ & $p$ & $\beta$ & $t$ & $p$ \\
\hline Constant & & 22.93 & $<.001$ & & 26.61 & $<.001$ & & 27.835 & .000 & & 28.581 & $<.001$ \\
\hline Gender & -.199 & -8.242 & $<.001$ & -.187 & -7.741 & $<.001$ & -.279 & -11.61 & .000 & -.166 & -6.824 & $<.001$ \\
\hline Economic status & -.087 & -3.56 & $<.001$ & -.097 & -4.049 & $<.001$ & .114 & 4.733 & .000 & & & \\
\hline Education & .056 & 2.287 & .022 & & & $<.001$ & & & & & & \\
\hline Age & .054 & 2.225 & .026 & .101 & 4.173 & $<.001$ & & & & & & \\
\hline Marital status & & & & & & & & & & .048 & 1.96 & .049 \\
\hline
\end{tabular}

The results exhibited that younger people, men, single people, and those who belong to the lower levels of socio-economic status, have less preventive behaviors. These results comply with a Knowledge, Attitude, and Practice (KAP) study, conducted in China, during the outbreak [24] .It was reported that in research in Hong Kong, $61.2 \%$ of the participants, always wore masks to prevent SARS [20]. The use of PPE decreases the chances of the virus spreading; however, it is not definitive. With the rapid spread of the virus, PPE is harder to supply, and hence, the spread happens at an even faster pace [25]. On March 3, 2020, WHO requested all countries to increase their production of PPE by at least $40 \%$, to meet the increased worldwide needs [26]. We believe that the reasons behind the lack of preventive behaviors in the mentioned groups could be due to lack of knowledge, lack of amenities, the belief of being resistant to the disease, and their higher potential for high-risk behaviors.

Social distancing and promotion of preventive behaviors are important solutions to break the chain of spread and flattening the disease curve. Educating the people about the concepts of the public health crisis promotes preventive behaviors among them, which in turn leads to the limitation of spread. Studies show that there is a chance of a repeated outbreak of the SARS virus; which can also be considered for the novel Corona Virus. Hence, it is necessary to educate and equip the public community with proper precautions to avoid a return of the epidemic. Moreover, Due to social distancing and limited physical contact, web-based data collection could be an advantage of the study.

\section{Limitations of the study}

One of the limitations of this study, is the being selfreported, retrospective, and without external observation. Hence, there is a chance of bias, due to peer pressure. There is also a chance of recalling bias, due to the study being, retrospective. Furthermore, considering less access to internet connection and smartphones among the elderly and the group with lower economic status, this study might not be a perfect representation of the Iranian population. Hence, conducting a larger study would be a better representation for the elderly and those with lower economic status.

\section{Conclusions}

The results show that according to the three main preventive behaviors of COVID-19 including handwashing, wearing masks and gloves, $50 \%$ of the population has not taken preventive behaviors seriously. It can also be concluded that these preventive behaviors have a significant relationship with some socio-demographic characteristics.

Table 4 Adjusted OR (Cl 95\%) variables effected prevention behavior against covid-19 ( $n=2097)$

\begin{tabular}{|c|c|c|c|c|c|c|c|c|c|c|c|c|c|}
\hline & & \multicolumn{3}{|c|}{ Individual behavior } & \multicolumn{3}{|c|}{ Entering Protocols } & \multicolumn{3}{|c|}{ leaving protocols } & \multicolumn{3}{|c|}{$\begin{array}{l}\text { Personal belongings } \\
\text { protocols }\end{array}$} \\
\hline & & OR & $\mathrm{Cl} 95 \%$ & $p$ & OR & $\mathrm{Cl} 95 \%$ & $p$ & OR & $\mathrm{Cl} 95 \%$ & $\mathrm{p}$ & OR & $\mathrm{Cl} 95 \%$ & $p$ \\
\hline Gender & Female vs. male & 1.67 & $1.288-2.168$ & $<.001$ & 1.99 & $1.57-2.51$ & $<.001$ & 2.67 & $2.005-3.567$ & $<.001$ & 1.804 & $1.44-2.25$ & $<.001$ \\
\hline Education & $\begin{array}{l}\text { < Graduate vs. } \\
\text { > Postgraduate }\end{array}$ & .726 & $.566-.931$ & .012 & .798 & $.639-.998$ & .048 & & & & & & \\
\hline $\begin{array}{l}\text { Economic } \\
\text { status }\end{array}$ & Good vs. Bad & 1.47 & $1.11-1.93$ & .006 & & & & & & & & & \\
\hline Marital status & Single vs. Married & & & & .737 & $.591-.920$ & .007 & .726 & $.575-.917$ & .007 & .792 & $.642-.976$ & .029 \\
\hline Age & $\leq 35$ vs. $>35$ years & & & & .703 & $.569-.869$ & .001 & & & & & & \\
\hline
\end{tabular}




\section{Supplementary Information}

The online version contains supplementary material available at https://doi. org/10.1186/s12889-021-10201-4.

Additional file 1: Supplementary file. Questionnaire of preventive behaviors during COVID-19 outbreak.

\section{Abbreviations}

WHO: World Health Organization; PPE: Personal Preventive Equipment

\section{Acknowledgments}

We would like to express our deepest gratitude to all the study participants for their voluntary participation, also to the Research and Technology Administration of Babol University of Medical Sciences, Babol, Iran for their support.

\section{Authors' contributions}

Literature review, data analysis and interpretation, and manuscript drafting was done by MF Literature review and data collection was done by SF, data collection was done by ASA, Study design, development of the questionnaire and the manuscript preparing was done by SO. All authors read and approved the final manuscript

\section{Funding}

None.

Availability of data and materials

Data is available on request from the corresponding author.

\section{Ethics approval and consent to participate}

The research protocol was approved by the Ethical Committee, Babol University of Medical Sciences (IR.MUBABOL.REC.1399.005). According to the nature of the study (being an online survey), filling the questionnaire was totally voluntary and the written consent form and all the explanations were displayed in the first page of the questionnaire; right before the main questionnaire. Then consent letter was obtained from all the participants before the start of the study.

\section{Consent for publication}

Not applicable.

\section{Competing interests}

The authors declare that they have no competing interests.

\section{Author details}

${ }^{1}$ Department of nursing- midwifery, Comprehensive Health Research Center, Islamic Azad University Babol Branch, Babol, Iran. ${ }^{2}$ Social Determinants of Health Research Center, Health Research Institute, Babol University of Medical Sciences, Babol, Iran. ${ }^{3}$ Bushehr University of Medical Sciences, Bushehr, Iran. ${ }^{4}$ Student of research committee, Babol University of Medical Sciences, Babol, Iran

Received: 23 May 2020 Accepted: 10 January 2021

Published online: 15 January 2021

\section{References}

1. Novel. Coronavirus Pneumonia Emergency Response Epidemiology. The epidemiological characteristics of an outbreak of 2019 novel coronavirus diseases (COVID-19) in China. Zhonghua liu xing bing xue za zhi= Zhonghua liuxingbingxue zazhi. 2020;41(2):145.

2. Chen $\mathrm{N}$, et al. Epidemiological and clinical characteristics of 99 cases of 2019 novel coronavirus pneumonia in Wuhan, China: a descriptive study. Lancet. 2020;395(10223):507-13.

3. Stebbing J, et al. COVID-19: combining antiviral and anti-inflammatory treatments. Lancet Infect Dis. 2020;20(4):400-2.

4. Gao J, Tian Z, Yang X. Breakthrough: Chloroquine phosphate has shown apparent efficacy in treatment of COVID-19 associated pneumonia in clinical studies. BioScience Trends. 2020;14(1):72-3.
5. World Health Organization. Coronavirus disease (COVID-2019) situation reports. 2020. https://www.who.int/emergencies/diseases/novelcoronavirus-2019/situation-reports. (Accessed 16 Feb).

6. Dong E, Du H, Gardner L. An interactive web-based dashboard to track COVID-19 in real time. Lancet Infect Dis. 2020;20(5):533-4.

7. http://www.euro.who.int/en/health-topics/emergencies/pages/news/news/2 020/01/2019-ncov-outbreak-is-an-emergency-of-international-concern. (Accessed on 16 Feb 2020).

8. https://www.who.int/emergencies/diseases/novel-coronavirus-2019. (Accessed on 8 Apr 2020).

9. http://dme.behdasht.gov.ir/index.aspx. (Accessed on 20 Mar 2020).

10. Ramont RP, Niedringhaus DM. Fundamental nursing care: Prentice Hall; 2004.

11. Black JM. Medical-surgical Nursing: Clinical Management for Positive Outcomes, 6e+ Winningham: Elsevier Saunders; 2001.

12. https://www.who.int/emergencies/diseases/novel-coronavirus-2019/advicefor-public. (Accessed on 20 Mar 2020).

13. https://www.cdc.gov/coronavirus/2019-ncov/prevent-getting-sick/ prevention.html.(Accessed on 20 Mar 2020).

14. Leppin A, Aro AR. Risk perceptions related to SARS and avian influenza: theoretical foundations of current empirical research. Int J Behav Med. 2009; 16(1):7-29.

15. Wong LP, Sam I-C. Temporal changes in psychobehavioral responses during the 2009 H1N1 influenza pandemic. Prev Med. 2010:51(1):92-3.

16. Brewer NT, et al. Risk perceptions and their relation to risk behavior. Ann Behav Med. 2004:27(2):125-30.

17. Østergaard C, et al. Bacteremia causes hippocampal apoptosis in experimental pneumococcal meningitis. BMC Infect Dis. 2010;10(1):1.

18. Lau JT, et al. SARS-related perceptions in Hong Kong. Emerg Infect Dis. 2005;11(3):417.

19. Borchgrevink CP, Cha J, Kim S. Hand washing practices in a college town environment. J Environ Health. 2013;75(8):18-25.

20. Tang CS-K, Wong C-Y. Factors influencing the wearing of facemasks to prevent the severe acute respiratory syndrome among adult Chinese in Hong Kong. Prev Med. 2004;39(6):1187-93.

21. Boutelle KN, et al. Associations between exercise and health behaviors in a community sample of working adults. Prev Med. 2000;30(3):217-24.

22. Liang $W$, et al. A population-based study of age and gender differences in patterns of health-related behaviors. Am J Prev Med. 1999;17(1):8-17.

23. Wolf MS, et al. Awareness, attitudes, and actions related to COVID-19 among adults with chronic conditions at the onset of the US outbreak: a cross-sectional survey. Ann Intern Med. 2020.

24. Zhong B-L, et al. Knowledge, attitudes, and practices towards COVID-19 among Chinese residents during the rapid rise period of the COVID-19 outbreak: a quick online cross-sectional survey. Int J Biol Sci. 2020;16(10): 1745-52.

25. Zhang Z, et al. Protecting healthcare personnel from 2019-nCoV infection risks: lessons and suggestions. Front Med. 2020:1-3.

26. Sahu KK, Mishra AK, Lal A. COVID-2019: update on epidemiology, disease spread and management. Monaldi Archives for Chest Disease. 2020;90(1): 197-205.

\section{Publisher's Note}

Springer Nature remains neutral with regard to jurisdictional claims in published maps and institutional affiliations.

\section{Ready to submit your research? Choose BMC and benefit from:}

- fast, convenient online submission

- thorough peer review by experienced researchers in your field

- rapid publication on acceptance

- support for research data, including large and complex data types

- gold Open Access which fosters wider collaboration and increased citations

- maximum visibility for your research: over $100 \mathrm{M}$ website views per year

At $\mathrm{BMC}$, research is always in progress.

Learn more biomedcentral.com/submission 